\section{Spring news}

Issues are flying hot and heavy this spring. Congress and the Bush Administration are involved in the tax and budget issues, but many important library issues are out there on the public agenda.

- On March 7, 2001, Senators Orrin Hatch (R-Utah) and Patrick Leahy (D-Vermont) introduced a bill to update the distance education provisions of the Copyright Act to account for advancements in digital transmission technologies that support distance learning. The bill, S. 487, is entitled the "Technology Education and Copyright Harmonization Act" (the "TEACH Act"). The new bill closely tracks the recommendations of the Copyright Office, which ALA welcomed as comprehensive and well-balanced. The ALA Washington Office is continuing to work closely with the Senate Judiciary Committee staff, other Senate staff, and the U.S. Copyright Office as this bill moves through the legislative process. We are also working with our partners in a distance education coalition to garner additional Senate sponsorship of the bill.

- We have been working successfully for several years to fend off introduction, in either the House of Representatives or the Senate, of a database protection bill. Proponents of database legislation, however, have repeatedly threatened to introduce legislation along the lines of one of the bills that was considered by the House in the last congressional session (H.R. 354). On March 29, Representative Billy Tauzin (R-Louisiana), House Energy and Commerce Committee chairman, and Representative Jim Sensenbrenner (R-Wisconsin), House Judiciary Committee chairman, announced that their two committees plan to work together to produce a database protection bill. They have invited the stakeholders to participate weekly over the next two months in open negotiations on how to approach such legislation. The Washington Office will be a participant in those meetings and will work with our coalition partners on strategies for the negotiations.

Lynne E. Bradley is Office of Government Relations director of ALA's Washington Office; e-mail: leb@alawash.org
- The "Electronic Dissemination of Government Publications" study report was published on March 30 by the Government Accounting Office (GAO). The congressionally mandated study examines the impact of providing documents solely in electronic format and assesses the feasibility of transferring the Federal Depository Library program to the Library of Congress. As part of the assessment of the depository library program, GAO: 1) identified how such a transfer might be accomplished; 2) identified measures that are necessary to ensure the success of such a transfer; 3) identified when such a transfer might optimally occur; 4) examined the functions, services and programs and administrative support of the Superintendent of Documents; and 5) examined and identified the costs for both GPO and the Library of Congress. The full report is available online at http://www.gao.gov/ new.items/d01428.pdf.

- On March 27, NCLIS released Volume 2 of their final report, "A Comprehensive Assessment of Public Information Dissemination," which includes NCLIS's proposal to create a new executive branch agency to consolidate and administer government information programs, such as the Federal Depository Library Program (FDLP) and the National Technical Information Service (NTIS). The NCLIS legislative and regulatory proposals will be further discussed at ALA Annual Conference in San Francisco, but many stakeholders from the library community have been lukewarm to the initial ideas. The report can be found at http://www.nclis.gov/govt/assess/assess.vol2. pdf.

- National Library Legislative Day (NLLD) is May 1 this year. We are pleased to learn that ACRL sponsored a special luncheon for the academic librarians participating. Even if you were unable to join your respective state delegations at Legislative Day, academic librarians are encouraged to "talk up" library legislative issues on campus and in the larger academic community. For more information about Legislative Day, visit http://www.ala.org/ washoff/legday.html. 


\section{The}

\section{Ultimate Online}

\section{Information Technology}

\section{Resource!}

Do your patrons or staff wish they had the latest technological development information and data at their fingertips?

Do they need around-the-clock access to a comprehensive collection of focused IT journals, magazines and conferences?

If so, then your institution needs a subscription to the w w w a c m.o r g/mem bers i p/librar y

\section{Your Institution's Greatest Asset!}

\section{The ACM Digital Library includes:}

Over 20 ACM publications and archives

15 years of conference proceedings

Advanced searching capabilities

Over 50,000 bibliographic citations

$700,000+$ pages of dounloadable text

\section{AN EXCEPTIONAL VALUE}

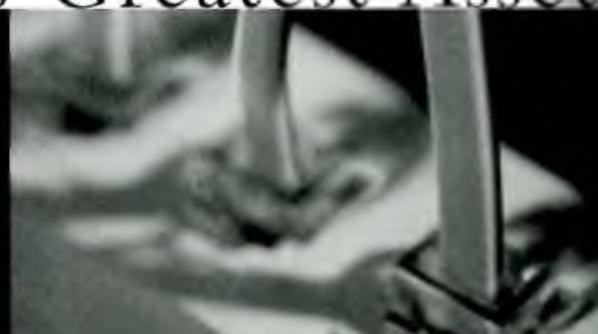

Contact ACM today to receive a FREE GIFT ${ }^{\star}$ for inquiring about the ACM Digital Library for your institution (while supplies last). Please mention code ADCRL21.

Academic Institutions, please contact:

ACM Member Services

e-mail: acmhelp@acm.org

phone: +1-212-626-0500

fax: +1-212-944-1318

Corporations and Consortia, please contact:

DL Coordinator

e-mail:dl-info@acm.org

phone: +1-212-626-0518

fax: +1-212-944-1318

* Limited to one per institution/organization. 